\title{
Is Dentistry Turning into Weary Profession? Dimensionality of Experienced Professional Burnout among Dentists in Central India
}

Ashish Dwivedi*, Bharathi Purohit and Ajay Bhambal

Goenka Research Institute of Dental Science, Gujarat, India

*Corresponding author: Ashish Dwivedi, People's College of Dental Sciences and Research Centre, Bhopal, Madhya Pradesh, India, Tel: 917898842426 ; E-mail: dr.ashishd86@gmail.com

Received date: Jul 21, 2016; Accepted date: Aug 10, 2016; Published date: Aug 19, 2016

Copyright: (ㄷ 2016 Dwivedi A et al. This is an open-access article distributed under the terms of the Creative Commons Attribution License, which permits unrestricted use, distribution, and reproduction in any medium, provided the original author and source are credited.

\begin{abstract}
Objective: Dentistry has been considered as an inspiring and rewarding profession but it is also equally challenging because of the physical and mental adversity it produces on the dentists. Dentists experience a variety of stressful factors all through their career resulting in professional burnout. The study was conducted to measure the level of burnout and implicated risk factors among dentists working in dental colleges of Central India.

Methodology: A total of 178 dentists working with at least 1 year of working experience were invited for the study, with a response rate of $87.5 \%$, a total of 155 dentists participated. Information about demographic and professional details from the dentists was recorded and were also asked to rate the Maslach Burnout Inventory (MBI).

Results: Mean MBI score was $60.38 \pm 9.95$. Mean scores for Emotional fatigue, Personal fulfillment, Depersonalization were $24.76 \pm 3.99,19.66 \pm 4.29$ and $15.94 \pm 3.44$ respectively. Among 22 factors of MBI Scale, four factors were extracted with eigenvalues above 2.0 by employing Factor Analysis with principal component analysis and varimax rotation.

Conclusion: In conclusion, the study highlights that over all burnout among the dentists was low and it was seen that dentists maintained a good relation with their recipients creating a favourable working environment. The study emphasizes the need to appraisal of burnout in diverse professions for a better understanding of personal, social and institutional variables, leading to attenuation of burnout.
\end{abstract}

Keywords: Maslach burnout inventory; Professional burnout; Dentistry

\section{Introduction}

Dentistry has been considered an inspiring and rewarding profession but it is also equally challenging because of the physical and mental adversity it produces on the dentists. Dentists experience a variety of stressful factors all through their career resulting in professional burnout. Various organizational and individual stress factors at dental school, in clinical practice building up all the way through, are responsible for professional burnout [1-3]. Burnout is a persistent, negative work-related state of mind in "normal" individuals, primarily characterized by emotional exhaustion and accompanied by distress, a sense of reduced effectiveness, decreased motivation, and the development of dysfunctional attitudes and behaviors at work [4]. Burnout leads to negative outcome on quality of work, affecting both professional and personal interests of a dentist. Recent studies have shown that professional workload, time constraint, and role conflicts are the important stressors in the development of burnout. Therefore, burnout risk assessment deserves continuous deliberations for subsequent prevention and intervention [5-7].

Several instruments have been used to measure burnout in health professionals but the Maslach Burnout Inventory (MBI) is considered to be the gold standard for assessing the burnout [8]. The MBI has three components: emotional exhaustion, depersonalization and personal accomplishment. Emotional exhaustion is considered a typical stress reaction due to prolonged exposure to work demands, whereas depersonalization is believed to be a way of coping with exhaustion by mentally isolating oneself from one's work particularly in relationship to the service recipient. As a consequence of exhaustion and depersonalization, a sense of reduced professional accomplishment or inefficacy might develop. Thus, burnout is considered to be a sequential process that develops over time [9-10].

Literature is not available from central India on the prevalence of burnout among dentists and hence the present study was conducted to assess level of burnout and implicated risk factors among dentists working in dental colleges of Bhopal.

\section{Methodology}

All the participating dentists in the study had completed five years graduation (Bachelor of Dental Surgery/BDS). In addition to this, the post graduate faculty had completed three years of Maters (Master of Dental Surgery/MDS) in any of the nine specialties after graduation. With the highest number of dental schools in the state, Bhopal has maximum number of dental faculty and hence dentists working in all the six dental schools of different universities were approached for the study. A total of 178 dentists working with at least 1 year of working experience were invited for the study, with a response rate of $87.5 \%$, a total of 155 dentists participated. The questionnaire was self- 
Citation: Dwivedi A, Purohit B, Bhambal A (2016) Is Dentistry Turning into Weary Profession? Dimensionality of Experienced Professional Burnout among Dentists in Central India. Dentistry 6: 391. doi:10.4172/2161-1122.1000391

Page 2 of 6

administered had two sections; the demographic and professional details were recorded in the initial part and Maslach Burnout Inventory (MBI) in the latter. The professional information included the participating dentist's qualification (graduation/post-graduation), nature of practice, whether academic or private and the dentists' experience in these areas. The Maslach Burnout Inventory (MBI) which measures 22 various aspects of professional burnout was applied in the present study. The items are measured on a with 5-point Likert scale ( $1=$ never burnout to $5=$ =veryday burnout) [11]. The study has been conducted in full accordance with the Helsinki declaration by World Medical Association. Institutional Ethical Committee (IEC code 2014PHD18) gave the approval for conducting the study and verbal informed consent from all the dentists was also obtained prior to the survey. Information from all the participating dentists was collected by a single investigator, ensuring anonymity of the information provided.

\section{Statistical Analysis}

Analysis of the data was done using SPSS (Statistical Package for the Social Sciences) version 22 (SPSS Inc., Chicago, IL, USA). Univariate and bivariate analysis was carried out to establish the association between independent variables on burnout. Further, Factor analysis (principle components, varimax rotation) was used to determine the association between the subsets of the burnout inventory. Significance was assumed at $<0.05$ (Table 1 ).

Table 2 presents percentage distribution of dentist's burnout level for different domains of Maslach Burnout Inventory. Under Emotional fatigue domain, $48.4 \%$ of the dentists never felt stressed out while working with people, while majority of dentists (43.9\%) agreed that they could easily create a relaxed atmosphere with recipients every day. Under Personal fulfillment domain, dentists never felt that they need not care about what happens to the recipients while a majority (34.8\%) of the dentists dealt with emotional problems very calmly every day. In Depersonalization domain $43.9 \%$ of the dentists agreed that the recipients never blamed them for any of their problems while one third of the dentists dealt very effectively with the problems of their recipients every day.

\begin{tabular}{|c|c|c|}
\hline Personal and professional characteristics & $\begin{array}{l}\text { Number } \\
\text { (N) }\end{array}$ & $\begin{array}{l}\text { Percentage } \\
(\%)\end{array}$ \\
\hline \multicolumn{3}{|l|}{ Age (years) } \\
\hline Less than 33 years & 97 & 62.6 \\
\hline More than 33 years & 58 & 37.4 \\
\hline \multicolumn{3}{|l|}{ Gender } \\
\hline Male & 74 & 47.7 \\
\hline Female & 81 & 52.3 \\
\hline \multicolumn{3}{|l|}{ Professional Qualification } \\
\hline B.D.S. Faculty & 37 & 23.9 \\
\hline M.D.S. Faculty & 118 & 76.1 \\
\hline \multicolumn{3}{|c|}{$\begin{array}{l}\text { Distribution of Dentists according to nature of } \\
\text { practice }\end{array}$} \\
\hline Academic only & 70 & 45.2 \\
\hline Both academic and private & 85 & 54.8 \\
\hline \multicolumn{3}{|c|}{ Distribution of dentists according academic experience } \\
\hline 1-6 years experience & 105 & 67.7 \\
\hline More than 6 years of experience & 50 & 32.3 \\
\hline \multicolumn{3}{|c|}{ Distribution of dentists according to private practice experience } \\
\hline $0-4$ years experience & 120 & 77.4 \\
\hline More than 4 years of experience & 35 & 22.6 \\
\hline Total & 155 & 100 \\
\hline
\end{tabular}

Table 1: Percentage distribution of dentists according to personal \& professional characteristics

\begin{tabular}{|c|c|c|c|c|c|c|c|c|c|c|c|}
\hline \multirow{3}{*}{ SI. no } & \multirow{3}{*}{ Questions } & \multicolumn{10}{|c|}{ Percentage distribution on 5 point Likert Scale } \\
\hline & & \multicolumn{2}{|c|}{ Never } & \multicolumn{2}{|c|}{ A few times a year } & \multicolumn{2}{|c|}{$\begin{array}{l}\text { A few times a } \\
\text { month }\end{array}$} & \multicolumn{2}{|c|}{$\begin{array}{l}\text { A few times a } \\
\text { week }\end{array}$} & \multicolumn{2}{|c|}{ Every day } \\
\hline & & $\mathbf{N}$ & $\%$ & $\mathbf{N}$ & $\%$ & $\mathbf{N}$ & $\%$ & $\mathbf{N}$ & $\%$ & $\mathbf{N}$ & $\%$ \\
\hline \multicolumn{12}{|c|}{ Emotional fatigue } \\
\hline 1 & I feel emotionally drained from my work & 19 & 12 & 62 & 40 & 56 & 36 & 16 & 10 & 2 & 1.3 \\
\hline 2 & I feel used up at the end of the work day & 22 & 14 & 45 & 29 & 63 & 41 & 19 & 12 & 6 & 3.9 \\
\hline 3 & $\begin{array}{l}\text { I feel fatigued when I get up in the } \\
\text { morning and have to face another day } \\
\text { on the job }\end{array}$ & 39 & 25 & 47 & 30 & 46 & 30 & 15 & 9.7 & 8 & 5.2 \\
\hline 6 & I feel frustrated by my job & 54 & 35 & 58 & 37 & 29 & 19 & 9 & 5.8 & 5 & 3.2 \\
\hline 8 & $\begin{array}{l}\text { Working with people directly puts too } \\
\text { much stress on me }\end{array}$ & 75 & 48 & 40 & 26 & 31 & 20 & 6 & 3.9 & 3 & 1.9 \\
\hline 13 & I feel very energetic & 3 & 2 & 9 & 5.8 & 24 & 16 & 55 & 36 & 64 & 41 \\
\hline 14 & $\begin{array}{l}\text { I can easily create a relaxed } \\
\text { atmosphere with my recipients }\end{array}$ & 5 & 3 & 9 & 5.8 & 30 & 19 & 43 & 28 & 68 & 44 \\
\hline
\end{tabular}


Citation: Dwivedi A, Purohit B, Bhambal A (2016) Is Dentistry Turning into Weary Profession? Dimensionality of Experienced Professional Burnout among Dentists in Central India. Dentistry 6: 391. doi:10.4172/2161-1122.1000391

Page 3 of 6

\begin{tabular}{|c|c|c|c|c|c|c|c|c|c|c|c|}
\hline 16 & $\begin{array}{l}\text { I have accomplished many worthwhile } \\
\text { things in the job }\end{array}$ & 5 & 3 & 36 & 23 & 58 & 37 & 34 & 22 & 22 & 14 \\
\hline 20 & $\begin{array}{l}\text { I worry that this job is hardening me } \\
\text { emotionally }\end{array}$ & 65 & 42 & 39 & 25 & 35 & 23 & 12 & 7.7 & 4 & 2.6 \\
\hline \multicolumn{12}{|c|}{ Personal fulfilment } \\
\hline 4 & $\begin{array}{l}\text { Working with people all day is really a } \\
\text { strain for me }\end{array}$ & 68 & 44 & 47 & 30 & 32 & 21 & 5 & 3.2 & 3 & 1.9 \\
\hline 7 & I feel I'm working too hard on my job & 28 & 18 & 52 & 34 & 41 & 27 & 20 & 13 & 14 & 9 \\
\hline 9 & I feel like I'm at the end of my rope & 89 & 57 & 29 & 19 & 26 & 17 & 8 & 5.2 & 3 & 1.9 \\
\hline 12 & $\begin{array}{l}\text { I feel I'm positively influencing other } \\
\text { people's lives through my work }\end{array}$ & 5 & 3 & 19 & 12 & 52 & 34 & 37 & 24 & 42 & 27 \\
\hline 17 & $\begin{array}{l}\text { In my work, I deal with emotional } \\
\text { problems very calmly }\end{array}$ & 6 & 4 & 19 & 12 & 36 & 23 & 40 & 26 & 54 & 35 \\
\hline 18 & $\begin{array}{l}\text { I feel I treat some recipients as if they } \\
\text { were impersonal 'objects' }\end{array}$ & 91 & 59 & 19 & 12 & 32 & 21 & 7 & 4.5 & 6 & 3.9 \\
\hline 19 & $\begin{array}{l}\text { I've become more callous toward people } \\
\text { since I took this job }\end{array}$ & 57 & 37 & 31 & 20 & 51 & 33 & 12 & 7.7 & 4 & 2.6 \\
\hline 21 & $\begin{array}{l}\text { I don't really care what happens to some } \\
\text { recipients }\end{array}$ & 93 & 60 & 31 & 20 & 16 & 10 & 10 & 6.5 & 5 & 3.2 \\
\hline \multicolumn{12}{|c|}{ Depersonalization } \\
\hline 5 & I feel burned out from my work & 54 & 35 & 57 & 37 & 26 & 17 & 14 & 9 & 4 & 2.6 \\
\hline 10 & $\begin{array}{l}\text { I can easily understand how my } \\
\text { recipients feel about things }\end{array}$ & 14 & 9 & 41 & 27 & 44 & 28 & 20 & 13 & 36 & 23 \\
\hline 11 & $\begin{array}{l}\text { I deal very effectively with the problems } \\
\text { of my recipients }\end{array}$ & 8 & 5 & 22 & 14 & 47 & 30 & 32 & 21 & 46 & 30 \\
\hline 15 & $\begin{array}{l}\text { I feel exhilarated after working closely } \\
\text { with my recipients }\end{array}$ & 18 & 12 & 13 & 8.4 & 60 & 39 & 40 & 26 & 24 & 16 \\
\hline 22 & $\begin{array}{l}\text { I feel recipients blame me for some of } \\
\text { their problems }\end{array}$ & 68 & 44 & 53 & 34 & 22 & 14 & 11 & 7.1 & 1 & 0.6 \\
\hline
\end{tabular}

Table 2: Distribution of burnout levels among dentists under various domains of Maslach Burnout Inventory

Mean MBI score was $60.38 \pm 9.95$. Mean and standard deviation for the subscales of the MBI are represented in Table 3. Mean scores for Emotional fatigue, Personal fulfillment, Depersonalization were 24.76 $\pm 3.99,19.66 \pm 4.29$ and $15.94 \pm 3.44$ respectively.

\begin{tabular}{|l|l|l|}
\hline & Mean & Standard deviations \\
\hline Emotional fatigue & 24.76 & 3.99 \\
\hline Personal fulfillment & 19.66 & 4.29 \\
\hline Depersonalization & 15.94 & 3.44 \\
\hline Total score & 60.38 & 9.95 \\
\hline
\end{tabular}

Table 3: Means and standard deviations for the subscales of the Maslach Burnout Inventory

Personal characteristics of the dentists were compared with total MBI scores and professional qualification was found to be significantly associated with total score of Maslach Burnout Inventory (Table 4).

\begin{tabular}{|l|l|l|l|}
\hline SI No & Demographic Variable & Chi-square value & p-value \\
\hline 1 & Age & 0.01 & 0.91 \\
\hline 2 & Gender & 1.39 & 0.23 \\
\hline 3 & Professional qualification & 4.05 & $0.04^{*}$ \\
\hline 4 & Nature of practice & 0.61 & 0.43 \\
\hline 5 & Academic experience & 0.10 & 0.74 \\
\hline 6 & Private practice experience & 0.43 & 0.50 \\
\hline${ }^{*}$ p-value<0.05, ${ }^{* *}$-v-value<0.01 & & \\
\hline
\end{tabular}

Table 4: Comparison of personal characteristics with Maslach Burnout Inventory

Factor analysis with principal components analysis and varimax rotation was conducted on all 22 items of MBI scale. Analysis of the eigenvalues and scree plot indicated that four factors could be 
Citation: Dwivedi A, Purohit B, Bhambal A (2016) Is Dentistry Turning into Weary Profession? Dimensionality of Experienced Professional Burnout among Dentists in Central India. Dentistry 6: 391. doi:10.4172/2161-1122.1000391

Page 4 of 6

extracted with values above $2.0: 3.34,2.74,2.74$ and 2.59 . The first factor, explained $15.19 \%$ of the variance and six items had loadings more than 0.5 on this factor. Similarly, the second factor explained $12.46 \%$ of the variance with three items loading above 0.5 . The third and fourth factors explained for $12.46 \%$ and $11.79 \%$ of the variance respectively with five items loading above 0.5 on each of these factors (Table 5).

\begin{tabular}{|c|c|c|c|c|c|}
\hline \multicolumn{2}{|c|}{ Eigen Value and Scale Variance } & \multicolumn{4}{|c|}{ Factor analysis for } \\
\hline & & Factor 1 & Factor 2 & Factor 3 & Factor 4 \\
\hline \multicolumn{2}{|c|}{ Eigen Value } & 3.34 & 2.74 & 2.74 & 2.59 \\
\hline \multicolumn{2}{|c|}{$\%$ Total scale variance } & 15.19 & 12.46 & 12.46 & 11.79 \\
\hline \multicolumn{6}{|c|}{ Questions } \\
\hline \multicolumn{6}{|c|}{ Emotional fatigue } \\
\hline 1 & I feel emotionally drained from my work & -0.049 & 0.219 & $0.609^{*}$ & -0.085 \\
\hline 2 & I feel used up at the end of the work day & 0.1 & 0.241 & $0.604^{*}$ & 0.002 \\
\hline 3 & $\begin{array}{l}\text { I feel fatigued when I get up in the morning and have to face another } \\
\text { day on the job }\end{array}$ & 0.029 & 0.048 & $0.699^{*}$ & 0.051 \\
\hline 6 & I feel frustrated by my job & -0.209 & 0.304 & $0.645^{*}$ & 0.164 \\
\hline 8 & Working with people directly puts too much stress on me & -0.165 & 0.751 & 0.018 & 0.231 \\
\hline 13 & I feel very energetic & $0.616^{*}$ & -0.143 & -0.265 & -0.02 \\
\hline 14 & I can easily create a relaxed atmosphere with my recipients & $0.682^{*}$ & -0.269 & -0.017 & -0.174 \\
\hline 16 & I have accomplished many worthwhile things in the job & $0.617^{\star}$ & 0.009 & -0.231 & 0.4 \\
\hline 20 & I worry that this job is hardening me emotionally & -0.113 & -0.008 & $0.506^{*}$ & $0.607^{\star}$ \\
\hline \multicolumn{6}{|c|}{ Personal fulfillment } \\
\hline 4 & Working with people all day is really a strain for me & -0.1 & $0.662^{*}$ & 0.403 & 0.047 \\
\hline 7 & I feel I'm working too hard on my job & 0.219 & $0.603^{*}$ & 0.261 & 0.087 \\
\hline 9 & I feel like I'm at the end of my rope & -0.255 & 0.434 & 0.261 & 0.354 \\
\hline 12 & I feel I'm positively influencing other people's lives through my work & $0.738^{*}$ & -0.005 & 0.104 & 0.097 \\
\hline 17 & In my work, I deal with emotional problems very calmly & 0.479 & -0.067 & -0.054 & -0.179 \\
\hline 18 & I feel I treat some recipients as if they were impersonal 'objects' & 0.099 & 0.315 & -0.158 & $0.587^{*}$ \\
\hline 19 & I've become more callous toward people since I took this job & 0.111 & 0.075 & 0.077 & $0.631^{*}$ \\
\hline 21 & I don't really care what happens to some recipients & -0.181 & -0.034 & 0.182 & $0.688^{*}$ \\
\hline \multicolumn{6}{|c|}{ Depersonalization } \\
\hline 5 & I feel burned out from my work & -0.15 & $0.732^{*}$ & 0.353 & 0.045 \\
\hline 10 & I can easily understand how my recipients feel about things & 0.46 & 0.276 & 0.253 & -0.348 \\
\hline 11 & I deal very effectively with the problems of my recipients & $0.673^{*}$ & -0.054 & 0.281 & -0.017 \\
\hline 15 & I feel exhilarated after working closely with my recipients & $0.610^{*}$ & 0.366 & -0.254 & 0.041 \\
\hline 22 & I feel recipients blame me for some of their problems & -0.088 & 0.191 & -0.109 & $0.655^{*}$ \\
\hline
\end{tabular}

Table 5: Item factor loadings for the Maslach Burnout Inventory 
Principal component analysis of Maslach Burnout Inventory, with varimax rotation yielded two main factors with eigen values above 4 . Factor 1 (3.34) and Factor 3 (2.74) loaded mainly on Emotional fatigue, factor 2 (2.74) and factor 4 (2.59) mainly on Personal fulfilment.

\section{Discussion}

Dentistry is certainly one of the most stressful professions with difficult and uncomfortable working conditions leading to professional burnout [12]. The present study is the first to be conducted among dentists of Central India to assess their professional burnout. With a mean age of $33.20 \pm 6.70$ years, the sample of dentists represented a young dental manpower. More than half of the dentists $(54.8 \%)$ were academicians with private practice. In the present study post graduate faculty $(76.1 \%)$ were thrice the graduate faculty, indicating improved professional opportunities for them.

More than one third of the dentists (41.3\%) felt very energetic and agreed that they could easily create a relaxed atmosphere with their recipients every day. Also, working with people never put too much stress on them and that they never worried every day that job was hardening on them emotionally, indicating less emotional fatigue among the dentists. The dentists dealt with emotional problems very calmly and positively influenced others people's lives through their work. More than half of the dentists agreed that they never treated the recipients as impersonal 'objects' and never had careless attitude towards recipients, but dealt very effectively with their problems everyday and hence never experienced being blamed by recipients for their problems.

Professional qualification emerged to be significantly associated with total MBI score, with more than half of the faculty (54.8\%) who were postgraduates having higher burnout than the remaining $45.2 \%$ graduate faculty indicating busy practice schedule leading to emotional stress. This could be also due to the need to cope with dual workload of academic work and private practice. Marion Vogt observed that a key factor influencing the risk of job burnout is working time [13]. Academicians who also had private practice were having longer working schedules as they have to balance both. Whereas the dentists who are only academicians tend to have a specified working time, thus they tend to have more time for themselves.

Studies conducted in other countries including the UK, the Netherlands and Finland concluded that about $12 \%-16 \%$ of the dentists were at risk of burnout [14-17]. Maslach and Jackson [18] reported higher level of burnout among females as compared to males which might due to role difference; women being in giving roles, eventually makes them susceptible to emotional exhaustion.

The factors which emerged with maximum loading were related to personal fulfilment domain with dentists positively influencing others through their work and easily creating a relaxed atmosphere with their recipients. The dentists feeling of burn out from work and feeling fatigued in the morning to face another day also had high factor loadings. This indicates the need to address these problems which might effectively decrease the burnout among dentists improving the overall work efficiency.

Apart from the above mentioned factors, burnout can also be seen as an indicator of the discrepancy between one's character or personal values and one's duties at work. So, there are, however, other factors related to our working life which contribute to burnout including lifestyle and certain personality characteristics like insufficient time for relaxation and social life, lack of close, supportive relationships which also need to be addressed. This is an essential aspect which needs to be addressed to help build the capacity of people within the working environment improving overall quality of work.

In conclusion, the study highlights that over all burnout among the dentists was low and it was seen that dentists maintained a good relation with their recipients creating a favourable working environment. The study emphasizes the need to appraisal of burnout in diverse professions for a better understanding of personal, social and institutional variables, leading to attenuation of burnout [19]. Such information will have the practical benefit the system of recruitment, professional training and work environment modification so as to lessen the burden.

\section{References}

1. Hornby AS (2010) Oxford advanced learner's dictionary. Oxford: Oxford University Press 1477

2. Newbury-Birch D, Lowry RJ, Kamali F (2002) The changing patterns of drinking, illicit drug use, stress, anxiety and depression in dental students in a UK dental school: a longitudinal study. Br Dent J 192: 646-649.

3. Kay EJ, Lowe JC (2008) A survey of stress levels, self-perceived health and health-related behaviors of UK dental practitioners in 2005. Br Dent J 204: E19.

4. Myers HL, Myers LB (2004) 'It's difficult being a dentist: stress and health in the general dental practitioner. Br Dent J 197: 89-93.

5. Gorter RC, Storm MK, Brake JHM, Kersten HW, Eijkman MAJ (2007) Outcome of career expectancies and early professional burnout amongst newly qualified dentists. Int Dent J 57: 279-285.

6. Te Brake H, Smits N, Wicherts JM, Gorter RC, Hoogstraten J (2008) Burnout development among dentists: a longitudinal study. Eur J Oral Sci 116: 545-551.

7. Maslach C, Jackson SE, Leiter MP (1997) MBI manual, 3rd edn. Palo Alto, CA: Consulting Psychologists Press, 1997.

8. Maslach C, Schaufeli WB, Leiter MP (2000) Job burnout. Annu Rev Psychol 52: 397-422.

9. Buunk BP, Schaufeli WB (1993) Burnout: A perspective from social comparison theory. In Professional burnout: Recent developments in theory and research. Series in applied psychology: Social issues and questions. Philadelphia: Taylor \& Francis pp: 53-69.

10. Van Dierendonck D, Schaufeli WB, Buunk BP (2001) Burnout and inequity among human service professionals: A longitudinal study. J Occup Health Psychol 6: 43-52.

11. Maslach C, Jackson SE (1986) The Maslach burnout inventory manual, 2nd edn. Palo Alto, CA: Consulting Psychologists Press.

12. Khanna R, Khanna R (2013) Is medicine turning into unhappy profession? Indian J Occup Environ Med 17: 2-6.

13. Maslach C, Jackson SE (1985) The role of sex and family variables in burnout. Sex Roles 12: 837-851.

14. Osborne D, Croucher R (1994) Levels of burnout in general dental practitioners in the south-east of England. Br Dent J 177: 372-377.

15. Gorter RC, Albrecht G, Hoogstraten J, Eijkman MAJ (1999) Professional burnout among Dutch dentists. Community Dent Oral Epidemiol 27: 109-116.

16. Te Brake JHM, Bouman AM, Gorter R, Hoogstraten J, Eijkman M (2007) Professional burnout and work engagement among dentists. Eur J Oral Sci 115: 180-185.

17. Murtomaa H, Haavio-Mannila E, Kandolin I (1990) Burnout and its causes in Finnish dentists. Community Dent Oral Epidemiol 18: 208-212.

18. Vogt M (2015) Caring professions at risk of job burnout. Eurofound. 
Citation: Dwivedi A, Purohit B, Bhambal A (2016) Is Dentistry Turning into Weary Profession? Dimensionality of Experienced Professional Burnout among Dentists in Central India. Dentistry 6: 391. doi:10.4172/2161-1122.1000391

Page 6 of 6

19. Maslach C, Jackson SE (1981) The measurement of experienced burnout. J Occup Behav 2: 99-113. 